\title{
Perception of Colombian Students from a Bachelor in Basic Education with Emphasis on Arts, about the Educational Quality of the Program They Study
}

\author{
Segura-Escobar Aldemar ${ }^{1} \&$ López-Vega Alfonso ${ }^{2}$ \\ ${ }^{1}$ Institute of Distance Education, Tolima University, Ibagué, Colombia y Doctorate in Language and Culture, \\ Pedagogical and Technological University of Colombia \\ ${ }^{2}$ Faculty of Science and Education, Francisco José de Caldas Distrital University, Bogotá, Colombia \\ Correspondence: Santa Helena Parte Alta, Ibagué, Colombia. Tel: 578-277-1212 Ext 9419. E-mail: \\ asegurae@ut.edu.co
}

Received: November 1, 2017 Accepted: December 10, 2017 Online Published: December 13, 2017

doi: $10.5539 /$ elt.v11n1p100

URL: http://doi.org/10.5539/elt.v11n1p100

\begin{abstract}
This article presents the results of a study about the attitudes by the learners from a bachelor in basic education with emphasis on arts, in Colombia, regarding the quality of academic management of this program. The importance of this study appears considers that its results will be useful to contrast the agreement or disagreement between the components of the management of quality, declared by bachelor programs, and recognized by the National Ministry of Education, and valued as satisfactory, based on the students' attitudes. All this will result in the development of analysis, design and execution of strategies which make possible the survival of the bachelor program, in an environment of governmental requirements on management of academic quality, and demands by the learners, which were not explicit before. The development of this project followed the survey method, with application of a questionnaire with the Likert's scale, with 20 variables and 7 assessment items. The population consisted of 380 students who were registered in the second semester of 2017, and the sample, not representative and selected with convenience, was of 33 learners. The results show satisfactory variables such as 1) contribution on social, political and cultural development; 2) existence of teaching criterion of artistic languages; 3) commitment to the training of qualified teachers; and 4) interdisciplinary nature. The other variables were valued as unsatisfactory. Of the total number of students surveyed, 39.4\% demonstrates an attitude of recognition of the bachelor as a program with academic quality; and a $60.6 \%$ has an explicit attitude of non-recognition.
\end{abstract}

Keywords: artistic education, quality of academic management, students' attitudes

\section{Introduction}

Colombian educational policies maintain a constant dynamic of modifications or redesigns of vocational training programs, looking for a management of the educational quality which can be demonstrated in the compliance of standards, increasingly higher, as indicated by Ochoa (2014). However, studies show that the basic parameters which assure the quality have not been reached, thus it was demonstrated with statistical data on Bases for the National Development Plan (2014-2018) (Departamento Nacional de Planeación, 2014).

In Colombia, a bachelor is an academic program which emphasis is teachers' education. These programs are presented to satisfy the need of teachers from different fields of knowledge, generally, inside the phases of preschool, primary and secondary school; despite of this, there are bachelor programs focused on educating teachers for universities, as well as no-formal education. Based on this, graduated students from the Bachelor in Basic Education with Emphasis on Arts, have an ample field of professional action.

Undergraduate programs must obtain qualified registration before starting operation; the granting of the registry is a recognition made by the National Ministry of Education (MEN in Spanish) to programs which fulfill the initial conditions of quality determined by the MEN to develop programs. From obtaining the qualified register and the operation of the program for a period stablished legally, this performs, at least, two self - assessments of compliance with the conditions of quality. Among the self - evaluation, it usually takes a time that allows appreciating differences in that fulfillment; if the program has advanced in it, it asks the MEN for accreditation; 
the latter develops the verification process, and decides whether or not to grant the requested recognition.

The so - called initial quality conditions are an abbreviated way of referring to the initial conditions of the management of educational quality, and the so - called conditions of accreditation of high quality make reference to the high quality of educational management, considering the approaches from theorists about quality of management and, mainly, of those who allude to it in the education field.

The initial conditions that a bachelor program in basic education must fulfill, were imposed by the Colombian president, through the order 2256 (2003); they were: 1) academic denomination of the program; 2) justification; 3) curricular aspects; 4) organization of the activities in academic credits; 5) training in research; 6) social projection; 7) students' election and evaluation; 8) academic personnel; 9) educational media; 10) infrastructure; 11) administrative and academic structure; 12) self - assessment; 13)policies and strategies for monitoring graduate students; 14) university welfare; 15) financial resources. This order also stablished parameters to be followed. In regards to high quality conditions, those parameters were stipulated by the National Accreditation Council (CAN in Spanish) (2006); they involve eight factors: 1) institutional mission and project; 2) students; 3 ) teachers; 4) academic processes; 5) institutional welfare; 6) organization, administration and management; 7) graduated students and their impact on the field; 8) physical and economical resources. Per each factor, a set of associated characteristics were associated (a total of 42 for all the factors); and for each characteristic, its aspects to evaluate and indicators.

The programs which aspire to obtain qualified register or high quality accreditation, create a reporting document with the compliance of the conditions, and the qualified instance, the National Council Quality Assurance of Higher Education (Conaces in Spanish) or the CNA, evaluate the completeness of the document, designate the evaluators who conduct the verification visit, and report it to the MEN. This ministry, considering the report by the evaluators and, in case of needing the more information or clarifications, it informs the University about them, determines whether or not the requested recognition is granted; and finally, it communicates the decision, by means of resolution and providing the legal resources.

The bachelor programs in basic education with emphasis on Arts began to be created from the presentation of the law 115 in 1994, which recognized artistic education as one of the fundamental areas in primary and secondary education. Initially, 28 programs were registered in the National System of Information on Higher Education (Snies in Spanish). In December, 2015, date of expedition of the resolution 02041 (MEN, 2016), which eliminates the possibility to create bachelor programs in basic education, or applying for register renewals for programs with this denomination, only 11 of them were reported as active $(39,28 \%)$ and, of these 11 programs, only two had high quality recognition. When a reduction of recently created programs occurs, in this case, $60,72 \%$ of the existing total in Colombia was closed, when, as contradiction, national and international educational policies maintain in validity, the need of teachers for this learning dimension and, when additionally, the number of programs with educational high quality management recognition is very low, we can point out that we are facing a problem which requires studies that contribute to clarify the core factors for the closures and the scarce high quality recognitions, in order to get bases that make possible the action on these factors, hence the interest on the development of this study.

\subsection{Validity of the Need of Artistic Education}

Diverse international organization have highlighted the need or seek artistic training since childhood; as stated, for instance, by the Organization of Ibero - american States (OEI in Spanish) (2012, p. 256), which presents, among the programs of action, shared by the signatory countries, the program of artistic education, culture and citizenship, remarking that the current social demands, and a new comprehension of the function of school education highlight the importance that the learners acquire the competences for learning to learn, learning to coexist, and learning to be and that, in this frame, the role of artistic education raises strongly, for an integrated training for people, and the construction of citizenship. By this way, it is understood that the formation of sensibility and artistic expression is a relevant strategy for the development of creative capacity, the self-esteem, disposition to learn, and abstract thought.

The same reference affirms that recent research point out the importance of arts in education, through artistic education and education for the art "as source for an integral and full development of children and young people, and as a transversal axis of learning which helps assimilate the other subjects of learning (...) for the construction of intercultural citizenship" (OEI, 2012, p. 256). Moreover, it presents, among other needs for the development of artistic education, to assure teachers' training.

The United Nations Organization for Education, Science and Culture (Unesco in Spanish) (2006) highlights that learning on arts and learning through arts may contribute to reinforcing four factors of quality of education: 1) 
learning; 2) a relevant and interesting curriculum for students; 3) knowledge of and with the community, the culture and the learners' local context; 4) qualified and motivated teachers.

The $23^{\text {rd }}$ Ibero - American Conference of Ministers of Education (2013) expressed its consideration that artistic education contributes to the development of intelligence and sensibility, and promotes coexistence.

The need of artistic education is not manifested from the field of educational policies. For example, Laignet (2012) states, from reflection on academic field, the need of joining learning sciences and arts, and highlights that education which includes ways of producing knowledge on arts, would be a great contribution for the renewal and improvement of the educational system, because it could lead to considering other possible ways of teaching, learning, producing and circulating knowledge. And that would also serve to transform institutional models into more flexible, pluralistic, inclusive and creative.

Since the exercise of the arts, it is not surprising to consider an education that lends, equally, attention to science and arts. Thus, education would lead us to think of new ways, to take advantage of our creativity; to create ethical and esthetic responses that allow us to give way to our desire to surpass each day; an education "that integrates science and arts into the family basket, according to the plans by a great poet of our time who asked not to continue loving them, as two sisters" (García, 1996, p. 29). In the same line, Ruiz (2016) expressed, putting in mind the need of an artistic education in which global and local artistic and scientific fields confluence, to strengthen sensibility and sensorial, and makes possible the development within the framework of culture that, at the same time, boosts.

A comprehension of arts education as a space of knowledge, expression, acknowledgement and acceptance of what is particular and diverse, prevails. Rodrigo (2008) understands arts education as a territory of clash, which integrates a cultural pedagogy with the collaborative artistic practices and community art, joining several disciplines, knowledge, ways and tools of work; institutions and cultural and educational workers. On the other hand, Juanola and Caibó (2017, p. 39) define esthetic and artistic education as a method to get closer to multicultural education, to design, comprehend and transform the conflicts that it is in.

The greater opening of the artistic expressions to give answers to the social needs, and a clearer acceptance of that which it enjoys, derives in the loss of the strict limits between the artistic disciplines, loss that has approximated the art and the craftsmanship, and has diversified the public. Chapato (2014, p. 15) highlights that change of social attitudes towards art, and an emergence of new questions about teaching, and it calls to the participation in the world of art, from artistic and cultural experience, contributes to develop the democratic life.

In the same line of argument, Escaño (2012) expresses his consideration about the responsibilities that artistic education has, in the construction of a democratizing education; it means, isolated to the meritocratic pretensions (in the sense of only accumulators of "merits" in a curriculum vitae) or exclusively professional (subjugated to the market criteria) which impose the factual powers which promote them. Respecting this, Gándara and Sánchez $(2007$, p. 9) highlight that the great paradox of artistic education is "educating in the disciplines and empowering their questioning".

\subsection{Aspects of Quality Management in Education, in Training Programs for Art Educators}

Managing the quality of education, in professional training programs, implies identifying what quality is. There are multiple meanings for this concept. According to the Spanish Association for Quality (AEC in Spanish) (s.f.):

Quality models are references that organizations use to improve their management. Those models, as difference with norms, do not contain requirements which must be fulfilled by quality management systems, but directions for improvement. There are quality models oriented to a total quality and excellence, models oriented to improvement, own models by determined sectors and, even, quality models which organizations develop (AEC, s.f.).

In accordance with the foregoing, the management of educational quality is based on one of two references: a model or a rule; in the case of the bachelor programs subject of this study, the reference was one of these, because MEN first issued the standard on recognition of compliance, with the minimum quality conditions and then, the Ministry offered documents which proposed a model of quality which the institutions could consider. Consequently, in both the models and the norms, it was clarified what was expected as quality management, in which elements it was precise to make action, and the adjustment of the reference would guarantee the fulfillment of all the stipulated parameters. In such a way, the identification of a quality program overcomes the subjective field of attitudes, to be placed in the objective field.

The concept of quality, in relation to the public service of higher education, makes possible that, from a synthesis of ideal characteristics, a relative distance between that foreseen idea and the institutions and programs which 
exist in the reality could be measured (CNA, 2006).

The National Accreditation Council (CNA) understands that quality demands a permanent process, to fulfill the functions on teaching, research, social projection and international cooperation; this process requires the design and achievement of strategic plans for the development of the project for each program and the institution; in the same way, it considers that self-evaluation and self-regulation are required.

Based on the document by the CAN, previously cited, the variables and categories of management of educational quality, in a bachelor in basic education with emphasis on arts, were identified. They were: development of a process of continuous improvement; a contribution to the social, political and cultural development; flexible curriculum; development, by the learners, of social teaching practices, where they confront theory and practice; validity of teaching criterion of artistic languages; commitment with training qualified professionals; a promotion of students' health; implementation of teaching methodologies which help learning; interdisciplinary nature; tutoring processes; supervision and attention to learners; availability of appropriated didactic and research infrastructure; development and presentation of research studies by the teachers; keeping alliances with cultural and educational institutions; having qualified directives; selecting their students and teachers, according to their academic merits; participation of their teachers and students in local, national and international academic and artistic interrelationship.

\subsection{Evaluation of Educational Quality Management}

In relation with an evaluation of quality management, the CAN (2006, p. 8) highlights three types of evaluation:

1) Self - assessment: It is a study that the institutions and academic programs develop, following the indications by the CAN, in relation to the parameters of what is necessary to consider. The leadership relies on the institution; the academic community must participate by an ample way.

2) External evaluation or by pairs: It is part of the document in which the results of the self - assessment study are presented; the evaluators verify those results and report an opinion about the quality, regarding different aspects.

3) The evaluation by CNA, which is based on the two previous aspects, and decides whether or not grating the requested recognition.

The CNA proposed a method which included the specification of factors, with their respective characteristics and factors, following what was stipulated by the national law, but making specifications. For the recognition of the minimum educational quality conditions of a program, eight indicators were formulated: 1) mission and institutional project; 2) students; 3) teachers; 4) academic procedures; 5) institutional welfare; 6) organization, administration and management; 7) graduated students and their impact in the context; and 8) physical and financial resources. Subsequently, the CNA (2013) determined other two factors for requests on high quality recognition: national and international visibility; and research, innovation and artistic and cultural creation.

Valdés (2008, p. 85 - 86) highlights the need of considering, in the evaluation of educational quality, pupils' learning, teachers' professional performance, an assessment of the effectiveness of educational policies, and the institution.

Taking into account that academic quality, as planned by CNA, implies the need for the programs to confer on the educational community for the self-assessment and peer assessment processes, it is necessary to take into account that, underlying the components evidenced by the norms and the recognized respective models, there are other components which have in bearing the reconnaissance that the academic communities can develop, in relation with the management of educational quality of a program, and which could interfere in that process. One of the underlying components is the criterion of subjective appreciation of quality, through attitudes.

Attitude is a concept with Latin origin, which means social motivation which foresees to make action towards determined objectives. There are personal attitudes, related to the individual's characteristics; and social attitudes, which interfere in group behavior. The attitude is related with the experiences; the attitudes are learnt in the framework of social activity, and affects in behaviors with objects and people, in determined circumstances (Rodriguez, 1991).

Although it is understood that attitudes have a certain trait of durability, they can be transformed; it is important, therefore, to identify attitudes towards specific realities that are negatively affected; the identification of attitudes can lead to proposing plans to transform the attitudes that are required, since, as pointed out by Escudero (1985), who refers definitions of attitude, based on several authors, cites a Shringhley (1983) in his description of attitude, mentioning the following characteristics: 
1) Attitudes are learnt; cognition interferes.

2) Attitudes predict behaviors.

3) Social influences affect the behaviors.

4) Attitudes are a layout to respond.

5) Attitudes are evaluative.

6) Feelings interfere in the attitudes.

Attitudes are "evaluation judgements, favorable or unfavorable, about objects, people or facts. They manifest the opinion of who talks about something". Attitudes have three components: cognition, affection and behavior. The cognitive component is composed by the opinions and beliefs; the affection one is composed by emotions or beliefs on that attitude, and the behavior component is the intention of behaving in a certain way with something or someone. These are connected, composing the attitude as a unit. In the same line, they indicate that attitudes are not the behavior, but this is related with the attitude. Studying them is studying symptoms, indicators; not the fact or real object as itself (Robbins \& Judge, 2009, pp. 75-77).

Despite of this, due to its potential incidence in the processes of educational quality management of the programs, it is important to characterize the attitudes that the program arouse in its apprentices for the knowledge is available as source for planning processes of improvement of the academic quality management of the program.

Based on what was mentioned before, the following objective was formulated for this study: To identify the attitudes that a group of students have, regarding the management of educational quality, of the bachelor program in basic education with emphasis on artistic education, currently studied in a Colombian university.

\section{Methodology}

\subsection{Identification of the Method}

An exploratory study was developed, with the application of the survey method by following the indicated for D'Ancona (2010, pp. 198-282)

\subsection{Characteristics of the Participants}

The sample was composed by 33 learners, from a group of 61 , who participated in a session of socialization of the self - assessment document, carried out on October $4^{\text {th }}, 2017$, in a rooms of the bachelor. The sample was collected by volunteer students who fulfilled the characteristic of the mentioned participation (Hernandez et al., p. 396)

\subsection{Survey Questionnaire}

An instrument was designed (survey questionnaire) with 20 variables and seven items; the variables were presented under the statement: The bachelor in basic education with emphasis on artistic education which you are studying, has as characteristics:

1) It has high academic quality.

2) It maintains a process of progressive improvement.

3) It contributes to the social, political and cultural development.

4) It has a flexible curriculum.

5) The teaching practicum that the students develop, give possibilities to a cross between theory and practice.

6) It considers that the different artistic languages are teachable.

7) It attempts training ideal teachers.

8) It promotes the students' health.

9) It implements teaching methodologies which benefit learning processes.

10) It is interdisciplinary.

11) It offers tutorials, a tracing and attention for the students.

12) It has appropriate didactic infrastructure.

13) It has appropriate research infrastructure.

14) Teacher develops and informs about their research studies. 
15) It keeps alliances with cultural and educational institutions.

16) It has ideal directives.

17) Their students are admitted, due to their academic excellence.

18) Their teachers are admitted, due to their academic excellence.

19) Their teachers participate in academic and artistic local, national and international relationships.

20) Their students participate in academic and artistic local, national and international relationships.

On the other hand, the assessment items were:

1) Absolutely disagree.

2) Strongly disagree.

3) Disagree.

4) Neither agree nor disagree.

5) Agree.

6) Strongly agree.

7) Absolutely agree.

The reliability of the instrument, internal consistence, was identified by the use of a query with two experts, who suggested adjustments in the semantic dimension, and subsequently, applying with the results of a pilot test; the Cronbach alpha method, to 30 people; two forms were discarded because they were incomplete; the alpha coefficient was 0.9 .

\section{Results}

The management of the data obtained permits affirming that, generally, the students have the perception that the Bachelor program of Basic Education with Emphasis on Arts, that they study, does not reveal the academic quality they expected.

The annex collects the data of scores assigned by the subjects of the variables.

As evidenced in this, only four of 20 variables were assessed with scores over 60 , considering 99 as the maximum score; those variables are equal to the $20 \%$ of the total; they were:

3) It contributes to the social, political and cultural development.

6) It considers that the different artistic languages are teachable.

7) It attempts training ideal teachers.

10) It is interdisciplinary.

The variable 3 is associated to the training projection; the number 6 alludes an epistemological aspect of the teaching methodology in the discipline - artistic field; the number 7 is related with training for the performance in arts education; and the 10 addresses contents and methodologies.

The variables assessed as less satisfactory constitute the $15 \%$ of the total number of variables; they were:

12) It has appropriate didactic infrastructure.

13) It has appropriate research infrastructure.

14) Teacher develops and informs about their research studies.

The variable 12 implies the didactic resources; and the 13 and 14 are related with research, its infrastructure, development and publication.

Regarding the average attitude towards all the variables on educational quality management, the results show that:

- $\quad$ Nine of the 33 polled students (27.2\%) expressed a satisfactory attitude, with a score over 40 points, considering 60 as the highest score.

- Seven students assess this process as unsatisfactory when giving a score under 10 points, considering the same 60 points; one of the apprentices assessed it as very unsatisfactory, when scoring with -11 points. 


\section{Discussion}

Located in the consideration of the components of the didactic models, as proposed by Álvarez (1999), we observed that the variables with no satisfaction are: didactic resources, infrastructure for research, and the development and publication of studies by teachers; in the reality of the professional training programs. These variables are joint with the management for the availability of economic resources, and the management of research and publications, which are aspects of educational quality management.

With regards to the development of research by teachers, this is a component of quality management of research and teaching and, due to the characteristics of articulation between professional training programs with other formative instances and the administrative institutions. This aspect of the educational quality management of the program, involves not only the bachelor program, but also the instances foreseen in the norms by the University where this career is developed, and in the institutional organization. In this case, it is required to continue in the inquiry of this topic because, in the academic community, there is conscience of the necessary relationship between knowledge and practice on arts, and teaching and research on arts. For this reason, it is necessary to validate if the students' unsatisfactory attitude corresponds with the reality of the teachers' research work, or if it is about pending communicative processes, in the same sense, it is highlighted that it is precise to inquire if the unsatisfactory attitude towards the publication of the research works, is based on the fact that they are not carried out, in the idea of a restricted disclosure in a single format, or in the lack of management of disclosure.

The importance of research by the teachers of the academic program, and its disclosure is advised as a construct which is derived from the requirements assigned to the learners, in order that they research. The idea of the educational activity, supported by education, has acquired strength. Mora and Osses (2012) warn the need of educational research in the artistic area in such a way that, for example, it can be realized what the processes are by which the theories on artistic education are expressed as teaching practices; they emphasize the importance of a research process that will make possible the reflection and reconstruction of teaching practices as a basis for their transformation. In the sense of pointing out the need of research on artistic education, Castro, Millán and Rivera (2011) indicated the appropriateness of analyzing the ways of articulation between science and methodology, discourse and work, and teaching and learning, in artistic education.

With regard to the attitude of dissatisfaction towards the adequacy of didactic infrastructure, the results demonstrate the need of collecting detailed data, aiming to determine their findings in reality, and to investigate the the types of infrastructure that, in the students ' discretion, it must be attended in a priority way, so that in the improvement plan, it is possible to collect this variable from the management of the educational quality of the program, and to project its attention.

It is important to consider that the vocational training programs in arts and artistic education find, in Information and Communication Technologies (ICTs), a source which many students appreciate as connatural in the didactic framework; in this way, Saura (2013, p. 461) answered a question regarding how arts teachers can acquire a greater efficacy in their work, affirming that it is possible with the "ArtEducación with the ICTs, a social network in which several artistic workshops are developed in digital format, online. The use of this space of relationships between teachers, but informal, allows its users putting in practice a lot of ideas related with $<$ learning by doing $>$ ".

From the analyzed results, there stems the need to keep going in depth in the analysis about the characteristics of the management of educational quality in the bachelor program, pointing to obtain the necessary resources to stablish the components of such management to intervene. Following this, the program could reach, each time with major certainty, the fulfillment of the standards imposed by the government, and that the recognition of such fulfillment is carried out, not only by the internal and external people in charge of the evaluation process, but also, by the majority of the members of the academic community who, while they develop an attitude of satisfaction towards the management of educational quality of the program, they will contribute to its progress.

\section{References}

Álvarez de Zayas, C. M. (1999). Didáctica. La escuela en la vida. La Habana: Pueblo y Educación.

Asociación Española para la Calidad. (XXXX). Modelos de Calidad. Retrieved from https://www.aec.es/web/guest/centro-conocimiento/modelos-de-calidad

Castro, R. K., Millán, M. y Rivera, N. (2011). El Papel de la Didáctica en la Educación Artística. Praxis Pedagógica, 11(12), 26-39. https://doi.org/10.26620/uniminuto.praxis.11.12.2011.26-39

D’Ancona, M. A. (2010). Fundamentos y Aplicaciones en Metodología Cuantitativa. Madrid: Síntesis. 
Chapato, M. E. (2014). Educación Artística Para el Siglo XXI. ¿Qué Docentes Necesitamos? Trayectoria. Práctica Docente en Educación Artística, (1), 5-16. Retrieved from http://www.ojs.arte.unicen.edu.ar/index.php/trayectoria/article/viewFile/114/102

Departamento Nacional de Planeación. (2014). Colombia la más Educada. In Bases del Plan Nacional de Desarrollo "Todos por un Nuevo Pais" 2014-2018. Versión preliminar para Discusión del Consejo Nacional de Planeación [Governmental Document]. Pp 1-22. Colombia. Retrieved from https://www.dnp.gov.co/CNP/Paginas/Documentos.aspx

Ministerio de Educación Nacional (2016). Resolución No. 02041 [Governmental Document]. Colombia. Retrieved from https://www.mineducacion.gov.co/1759/articles-356982_recurso_1.pdf

Congreso de la República de Colombia (1994). Ley General de Educación [Governmental Document]. Retrieved from http://www.mineducacion.gov.co/1621/articles-85906_archivo_pdf.pdf

Consejo Nacional de Acreditación (2006). Guía Para la Renovación de la Acreditación de Programas Académicos de Pregrado. Bogotá: CNA.

Consejo Nacional de Acreditación. (2006). Lineamientos Para la Acreditación de Programas. Bogotá: CNA. Retrieved from http://www.mineducacion.gov.co/CNA/1741/articles-186359_lineamientos_2.pdf

Consejo Nacional de Acreditación. (2013). Lineamientos Para la Acreditación de Programas de Pregrado. Bogotá: CNA. Retrieved from https://www.cna.gov.co/1741/articles-186359_pregrado_2013.pdf

Escaño, C. (2012). (Edu) comunicación (artística) y Poder. Reflexión y Prácticas en Red Desde la Pedagogía Crítica Para una Democratización de la Educación Artística en Tiempo de Crisis. Arte, Educación y Cultura. Aportaciones Desde la Periferia. Retrieved from http://www.educacionartistica.es/aportaciones/1_comunicaciones/politizacion/131_esca\%C3\%B1o_comuni cacion_poder.pdf

Escudero, E. (1985). Las Actitudes en la Enseñanza de las Ciencias: un Panorama Complejo. Revista de Educación, 278, 5-26.

Gándara, R. E., \& Sánchez, M. V. (2013). Arte y Participación. Espacio Público y Educación Artística. Revista LINDES. Estudios Sociales del Arte y la Cultura, 7. Retrieved from http://www.revistalindes.com.ar/contenido/numero7/nro7_art_sanchez-gandara.pdf

García, G. (1996). La Proclama: Por un País al Alcance de los Niños. In Informe de la Misión de Sabios. Colombia: al Filo de la Oportunidad. Misión Ciencia, Educación y Desarrollo. Bogotá: Tercer Mundo. Retrieved from http://www.plandecenal.edu.co/cms/media/herramientas/colombia_al_filo_de_la_oportunidad.pdf

Hernández, R., Fernández, C. y Lucio, M. (2010). Metodología de la Investigación. México: McGraw-Hill.

Juanola, R., \& Calbó, M. (2007). La Educación Estético - Artística y el Museo. Un Link por sus Recorridos Comunes. In Huerta, R. \& De la Calle, R. Espacios Estimulantes. Museos y Educación Artística.

Laignelet, V. (2012). Existe la Regla y Existe la Excepción. Aproximaciones a una Pedagogía Poética Desde las Artes. Creación, Pedagogía y Políticas del Conocimiento. Memorias de un Encuentro. (pp. 121-139). Bogotá: Universidad Jorge Tadeo Lozano.

Mora, J. M. y Osses, S. (2012). Educación Artística para la Formación Integral. Complementariedad entre Cultura Visual e Identidad Juvenil. Estudios Pedagógicos, 38(2).

Ochoa, M. L. (2014). Lineamientos de Calidad Para las Licenciaturas en Educación. Versión Preliminar. Colombia: Ministerio de Educación Nacional. Retrieved from http://www.mineducacion.gov.co/cvn/1665/articles-340962_recurso_1.pdf

Organización de Estados Iberoamericanos. (2012). Metas 2021. La Educación que Queremos Para la Generación de los Bicentenarios. Madrid: OEI. Retrieved from http://www.oei.es/historico/metas2021/libro.htm

Organización de las Naciones Unidas para la Educación y la Cultura. (2006). Hoja de Ruta Para la Educación Artística. Conferencia Mundial sobre la Educación Artística. Lisboa. Retrieved from http://www.unesco.org/fileadmin/multimedia/HQ/CLT/CLT/pdf/Arts_Edu_RoadMap_es.pdf

Presidencia de la República (2003). Decreto 2566. Colombia. Retrieved from http://www.alcaldiabogota.gov.co/sisjur/normas/Norma1.jsp?i=9964 
Rodrigo, J. (2008). Educación Artística y Prácticas Artístico - Colaborativas: Territorios de Cruce Transversales. Junta de Castilla Y León. Arte Contemporáneo y Educación: un Dialogo Abierto. 76 - 96. Valladolid. Retrieved from http://www.opa-a2a.org/dissensus/wp-content/uploads/2008/05/rodrigo_javier_educacion_artistica_y_practi cas_artisticas_colaborativas.pdf

Robbins, S. P. y Judge, T. A. (2009). Comportamiento Organizacional (13 ${ }^{\text {th }}$ Edition). México: Pearson Educación.

Rodríguez, A. (1991). Psicología Social. México: Trillas

Ruíz Solórzano, J. (2016). Aproximación a la Epistemología de la Educación Artística. Paideia Surcolombiana, $11,13-30$.

Saura, A. (2013). E@: Red Social Para la Educación Artística Abierta y a Distancia, Para la Formación Continua del Profesorado. Estudios Sobre el Mensaje Periodístico, 19, 459-468.

Valdés, H. (2008). Hacia una Evaluación del Desarrollo y Formación Corporal, Racional y Emocional del Ser Humano: El caso Cubano. Organización de las Naciones Unidas Para la Educación, la Ciencia y la Cultura. Reflexiones en Torno a la Evaluación de la Calidad Educativa en América Latina y El Caribe. pp. 68-87. Santiago de Chile: UNESCO. http://unesdoc.unesco.org/images/0017/001776/177648S.pdf

XXIII Conferencia Iberoamericana de Ministros de Educación. (2013). Declaración de la XXIII Conferencia Iberoamericana de Ministros de Educación. Panamá. Disponible en http://www.oei.es/noticias/spip.php?article12931

Annex: Scores by the participants of this study, to the variables of management of educational quality

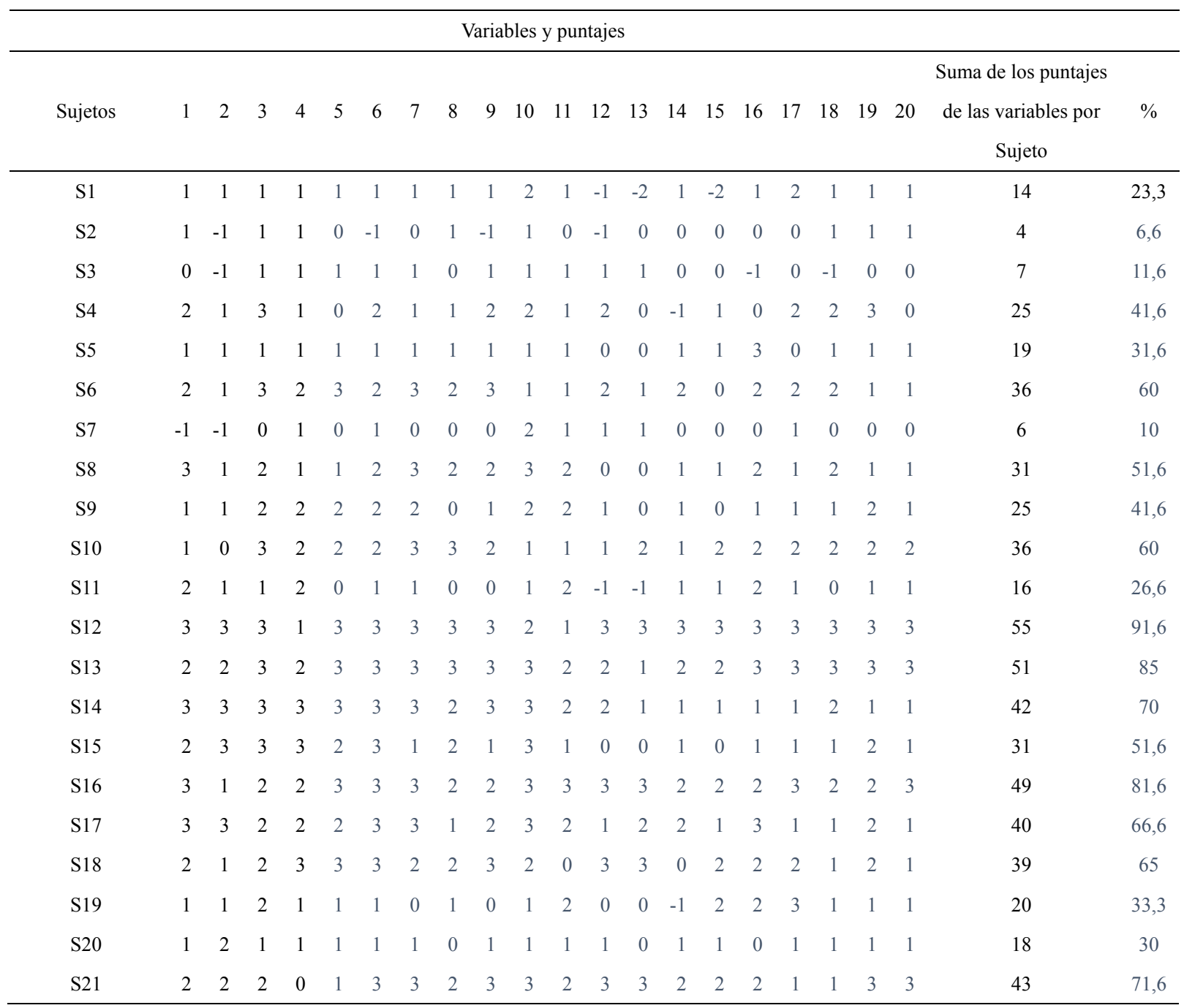




\begin{tabular}{|c|c|c|c|c|c|c|c|c|c|c|c|c|c|c|c|c|c|c|c|c|c|c|}
\hline $\mathrm{S} 22$ & 3 & 2 & 2 & 3 & 3 & 3 & 3 & 2 & 3 & 3 & 1 & 1 & 0 & 1 & 3 & 2 & 2 & 3 & 3 & 3 & 46 & 76,6 \\
\hline $\mathrm{S} 23$ & 3 & 3 & 3 & 2 & 2 & 3 & 3 & 3 & 2 & 3 & 1 & -2 & 0 & 0 & 2 & 3 & 2 & 3 & 3 & 3 & 42 & 70 \\
\hline $\mathrm{S} 24$ & 1 & 0 & 2 & 1 & -1 & 1 & 1 & 0 & -2 & 1 & 0 & -2 & -3 & -3 & -2 & -1 & 2 & 0 & -3 & -3 & -11 & $-18,3$ \\
\hline $\mathrm{S} 25$ & 3 & 1 & 2 & 1 & 2 & 3 & 2 & 2 & 2 & 3 & 2 & 3 & 2 & 2 & 2 & 2 & 2 & 3 & 2 & 0 & 41 & 68,3 \\
\hline $\mathrm{S} 26$ & 1 & 2 & 1 & 2 & 2 & 3 & 1 & 2 & 3 & 1 & 1 & 1 & 0 & 0 & 0 & 1 & 1 & 3 & 2 & 1 & 28 & 46,6 \\
\hline $\mathrm{S} 27$ & 3 & 2 & 1 & 1 & 1 & 3 & 3 & 1 & 2 & 3 & 3 & -1 & 1 & 1 & 1 & 0 & 2 & 2 & 2 & 2 & 33 & 55 \\
\hline $\mathrm{S} 28$ & 1 & 1 & 0 & 2 & -1 & 2 & 2 & 2 & 0 & 1 & -1 & -2 & -2 & 1 & 0 & 1 & 1 & 1 & 1 & 1 & 11 & 18,3 \\
\hline $\mathrm{S} 29$ & 1 & 0 & 3 & 0 & 0 & 3 & 3 & 3 & 0 & 3 & 3 & -3 & -1 & -3 & 0 & 2 & -1 & -2 & 1 & 1 & 13 & 21,6 \\
\hline $\mathrm{S} 30$ & 0 & -1 & 0 & 1 & 1 & 1 & 0 & 1 & 1 & 1 & 0 & -1 & -1 & -1 & 0 & 0 & 0 & -1 & 1 & -1 & 1 & 1,6 \\
\hline $\mathrm{S} 31$ & 0 & 1 & 1 & 1 & -1 & 0 & 1 & 0 & 0 & 1 & 0 & -1 & 0 & 0 & 1 & 1 & 1 & 0 & 0 & 0 & 6 & 10 \\
\hline $\mathrm{S} 32$ & 0 & -1 & 1 & 0 & 1 & 1 & 0 & 1 & -1 & 1 & 0 & -2 & -1 & 1 & 0 & -1 & 0 & 0 & 1 & 1 & 2 & 3,3 \\
\hline S33 & 2 & 1 & 3 & 3 & 2 & 3 & 2 & 3 & 2 & 3 & 1 & 1 & 1 & 2 & 2 & 2 & 2 & 2 & 1 & 1 & 39 & 65 \\
\hline Suma de los & & & & & & & & & & & & & & & & & & & & & & \\
\hline puntajes por & 53 & 36 & 60 & 50 & 44 & 66 & 59 & 49 & 45 & 65 & 40 & 15 & 14 & 21 & 29 & 43 & 45 & 41 & 47 & 36 & & \\
\hline
\end{tabular}

\section{Copyrights}

Copyright for this article is retained by the author(s), with first publication rights granted to the journal.

This is an open-access article distributed under the terms and conditions of the Creative Commons Attribution license (http://creativecommons.org/licenses/by/4.0/). 